\title{
Linguocultural Localization of Movie Titles
}

\author{
Vladislav E. Anissimov ${ }^{1}$, Anna S. Borissova ${ }^{1}$, Grigoriy R. Konson ${ }^{2}$ \\ ${ }^{1}$ RUDN University \\ 6, Miklukho-Maklaya St., Moscow, 117198, Russia \\ ${ }^{2}$ Russian State Social University \\ 4/8, ul.Vilgelma Pika, Moscow, 129226, Russia
}

\begin{abstract}
Due to intensive growth of film production and the expansion of the "market of film consumption", the need for high-quality translation of feature films into different languages is becoming more and more pressing. While a foreign language film is localized, text elements are not only translated, but also adapted to the culture of the target audience, i.e. we are witnessing transition from one language and cultural code to another. Taking into account their structural, semantic, and functional pragmatic features, film titles are vivid representative materials for the study of modern translation practices in the light of the cultural transference concept (Bassnett 2005, Bastin 1990, Cranmer 2015, Jurt 2007, Katan 1999, Leinen 2007, Thill 2007, Schreiber 1998, Slyshkin, Efremova 2004, Obolenskaya 2013, Snetkova 2009, Fedorova 2009). The purpose of the article is to identify the strategies of linguocultural localization of French film names for the modern Russian-speaking audience, as well as to determine the degree of its adequacy. Regardless of the choice of the translation strategy, the title should correspond to the plot, thematic focus and ideological and figurative content of the film, while remaining interesting and attractive to the audience. We analysed of eighty-seven French feature films of various genre affiliations (detectives, action films, dramas, melodramas, comedies, thrillers and fantasy), released in Russian from 2000 to 2018, and their translation equivalents. We used the methods of semantic, pragmatic, contextual and linguocultural analysis to identify a set of problems arising in the process of localization of film titles and to offer recommendations for their translation into Russian, considering the communicative specifics of the modern film discourse and the ethnic and cultural characteristics of the target audience.
\end{abstract}

Keywords: film titles, translation, localization, cultural transfer, translation strategy

For citation:

Anissimov, Vladislav E., Borissova, Anna S., Konson, Grigoriy R. (2019). Linguocultural Localization of Movie Titles. Russian Journal of Linguistics, 23 (2), 435 - 459. doi: 10.22363/2312-9182-2019-232-435-459.

\section{Лингвокультурная локализация кинозаголовков}

\author{
В.Е. Анисимов, А.С. Борисова, Г.Р. Консон \\ Российский университет дружбы народов \\ ул. Миклухо-Маклая, д. 6, Москва, 117198, Россия \\ Российский государственный социальный университет \\ ул. Вильгельма Пика, д. 4 cm. 8, Москва, 129226, Россия
}

\begin{abstract}
Аннотация
В связи с интенсивным ростом кинопроизводства и расширением «рынка кинопотребления» возрастает необходимость в качественном переводе текстов художественных фильмов на разные языки. В процессе локализации иноязычной киноленты осуществляется не только перевод ее
\end{abstract}


текстовых элементов, но и адаптация к культуре целевой аудитории, т.е. происходит переход от одного языкового и культурного кода к другому. Кинозаголовки с учетом их структурносемантических и функционально-прагматических особенностей представляют собой яркий репрезентативный материал для исследования современных переводческих практик в свете концепции культурного переноса (Bassnett 2005, Bastin 1990, Cranmer 2015, Jurt 2007, Katan 1999, Leinen 2007, Thill 2007, Schreiber 1998, Слышкин, Ефремова, 2004, Оболенская 2013, Снеткова 2009, Федорова 2009). Цель статьи заключается в выявлении стратегий лингвокультурной локализации французских фильмонимов для современной русскоязычной аудитории, а также определении степени ее адекватности в каждом конкретном случае. Независимо от выбора переводческой стратегии название должно соответствовать сюжету, тематической направленности и идейно-образному содержанию фильма, при этом оставаясь интересным и привлекательным для массового зрителя. Материалом послужили названия 87 французских художественных фильмов различной жанровой принадлежности (детективы, боевики, драмы, мелодрамы, комедии, триллеры, фантастика), выходившие в российский прокат с 2000 по 2018 годы, и их переводные эквиваленты. В работе использовались методы семантического, прагматического, контекстуального и лингвокультурологического анализа. Данные методы позволили обозначить комплекс проблем, возникающих в процессе лингвокультурной локализации кинозаголовков, и предложить рекомендации по их переводу на русский язык с учетом коммуникативной специфики современного кинодискурса и этнокультурных особенностей целевой аудитории.

Ключевые слова: фильмонимы, перевод, локализация, культурный перенос, переводческая стратегия

\section{Для цитирования:}

Анисимов В.Е., Борисова А.С., Консон Г.Р. Лингвокультурная локализация кинозаголовков // Вестник Российского университета дружбы народов. Серия: Лингвистика = Russian Journal of Linguistics. 2019. T. 23. No 2. C. 435 - 459. doi: 10.22363/2312-9182-2019-23-2-435-459.

\section{1. ВВЕДЕНИЕ}

В последние десятилетия наблюдается увеличение экспорта фильмов за пределы страны-производителя. С начала 2000-х годов французские компании активно инвестируют средства в маркетинг и дистрибуцию национальных фильмов на большом количестве зарубежных рынков, в том числе и российском. По данным информационного портала “CINEMOTION”, Россия является для Франции 4-м по величине рынком по «бокс-офису» и 5-м по количеству зрителей, приходящих в кинотеатры на просмотр французских кинокартин ${ }^{1}$. В 2018 году в российский прокат вышла 171 кинолента либо исключительно французского производства, либо в копродукции с другими странами ${ }^{2}$. Необходимость осуществлять продвижение кинопродукции в новой лингвокультурной среде обуславливает потребность в ее качественном переводе на разные языки.

Знакомство с фильмом, в независимости от его жанрово-тематической направленности и формата (массовое / независимое авторское кино), начинается с его названия, определяемого некоторыми отечественными лингвистами как фильмоним (Александрова 2016, 2017, Кныш 1998, 1992, Лукин 1999, Милевич 2007, 2012, Подымова 2006). Перевод фильмонимов приобретает особое значение, т.к.

1 Бокс-офис - термин, обозначающий выручку от продажи билетов, используемый в кинотеатральном прокате.

${ }^{2}$ http://www.cinemotionlab.com. 
именно они являются отправной точкой репрезентации киноленты, определяют тот эффект, который она даст в прокате, и сохраняют впечатление о ней в памяти зрителя. «Название - это не просто 20-30 знаков с пробелами... это еще и лицо, имя фильма...» (Бузаджи 2005:64). Неадекватный перевод кинозаголовка может ввести реципиента в заблуждение и негативно повлиять на восприятие всего произведения в целом. Кроме того, переводчику следует помнить о том, что в случае успешности кинокартины в прокате, название под которым она фигурировала войдет в национальную, а может и мировую культуру. Оно может стать источником различных «текстовых реминисценций (упоминаний, цитат, аллюзий), существующих в сознании носителя языка и реализующихся в повседневной коммуникации» (Слышкин, Ефремова 2004:8).

При локализации иноязычных фильмонимов осуществляется не только перевод исходных текстовых элементов, но и адаптация к культуре целевой аудитории, т.е. переход от одного языкового и культурного кода к другому. Сложность перевода кинозаголовков также обусловлена пересечением художественного и коммерческого дискурсов. Перед переводчиком стоит трудный выбор между верностью оригиналу, раскрывающему содержание киноленты, ее жанр, авторский замысел, и ориентацией на рекламные/коммерческие цели. Как отмечает К. Норд, настаивать на исключительной «верности» (“faithful” translation) оригинальному названию малоэффективно. В киноиндустрии против буквального перевода существует множество аргументов, и не только лингвистических (Норд 2019). В этой связи справедливо высказывание Р. Клер о том, что «...между мозгом, который задумывает фильм, и экраном, который дает отражение, лежит целая промышленная организация и ее финансовые нужды» (Клер 1981:151). Также необходимо подчеркнуть, что лингвокультурная локализация кинозаголовков это коллективное творчество. В этом процессе, с разной степенью влияния на результат, могут принимать участие сразу несколько переводчиков, дистрибьютерские компании и рекламные агентства. Решающее слово, как правило, остается за последними.

Цель статьи заключается в выявлении стратегий перевода названий французских художественных фильмов на русский язык в свете концепции культурного переноса. Независимо от выбора переводческой стратегии название должно соответствовать сюжету, тематической направленности и идейно-образному содержанию фильма, при этом оставаясь лаконичным, звучным, эмоциональным, запоминающимся и привлекательным для массового зрителя. Корпус исследования составили 87 названий французских разножанровых кинокартин, вышедших в российский прокат в 2000-2018 гг. Фильмонимы анализировались с точки зрения степени соответствия оригинальному названию и степени адекватности лингвокультурной адаптации ${ }^{3}$. Авторам статьи удалось очертить круг проблем, возникающих в процессе локализации франкоязычных кинозаголовков, и пред-

\footnotetext{
3 При анализе степени адекватности перевода названий французских художественных фильмов проводился опрос респондентов. Результаты анкетирования представлены в разделе 5 данной статьи.
} 
ложить рекомендации по переводу на русский язык с учетом их лингвистических и функциональных особенностей, а также этнокультурной специфики целевой аудитории.

\section{2. КИНОПЕРЕВОД: КОНЦЕПЦИЯ КУЛЬТУРНОГО ПЕРЕНОСА}

Кино является важной частью социального бытия современного человека, одним из основных средств его приобщения к событиям окружающей действительности, «зеркалом культуры» и посредником в ее формировании. Кинофильмы функционируют в пространстве и времени, создают уникальную художественную модель жизни во всем многообразии ее проявлений и, наряду с художественной литературой, публицистикой, непосредственным общением с носителями языка являются источником языковедческой и культуроведческой информациии. Как отмечают исследователи, кинотекст, в отличие от любого другого вербального произведения, характеризуется большей степенью «вовлеченности в процесс межукультурной коммуникации» (Слышкин, Ефремова 2004: 8).

В последние десятилетия наблюдается значительное повышение научного интереса к кино, не только как к особому виду аудиовизуального искусства, но и в лингвистическом и переводоведческом ракурсе. Отечественные и зарубежные исследования, отражающие непосредственно специфику киноперевода, затрагивают весьма обширный спектр вопросов, в числе которых: трудности межсемиотического характера, с которыми неизбежно сталкивается переводчик в процессе работы с кинотекстом; философско-герменевтические аспекты смысловой предельности в переводе; культурологические аспекты киноперевода, обуславливающие выбор форм, стратегий и приемов для адекватной адаптации кинопроизведения в принимающей культуре (Анисимова 2003, Бузаджи 2005, 2006, 2008 , Бусел 2017, Гарбовский 2004, Горшкова 2006, 2014, 2016, Зарецкая 2012, Коркмаз Казым Аныл 2017, Назмутдинова 2014, Новикова 2017, Оболенская 1998, 2006 , Слышкин, Ефремова, 2004, Сдобников 2006, Снеткова 2009, Федорова 2009; Ballard 2005, Boillat, Cordonier 2013, Catteau 2011, Gambier 2002, Jullier 2012, Valentini 2011).

В данной статье перевод иноязычного кинотекста в целом и кинозаголовков в частности рассматривается как культурно-обусловленный процесс. В этой связи особый интерес вызывает концепция культурного переноса "Les transfers culturels", разработанная в конце 80-х годов прошлого столетия французскими филологами-германистами М. Espagne и M. Werner. Ученые занимались изучением межкультурного взаимодействия “...comme un objet historique, qui s'est concrétise dans des textes, des documents, puis dans un discours idéologique collectif à ce que nous appelons la construction d'une reference...” (Espagne, Werner 1987: 969)4 .

На сегодняшний момент культурный перенос различных художественных произведений посредством перевода - это одно из наиболее актуальных иссле-

4 «..как исторических объектов, конкретизирующихся в текстах, документах, а впоследствии в коллективном идеологическом дискурсе, т.е. в процессе построения референции...» (Здесь и далее перевод авторов статьи). 
довательских направлений. По мнению французских языковедов, культурный перенос сам по себе является переводом, так как предполагает переключение кодов, т.е. переход текста от одного языка-культуры к другому (Jurt 2007, Thill 2007). Главная задача заключается в исследовании восприятия произведений искусства в принимающей среде. Киноперевод ориентирован «на оказание художественно-эстетического воздействия и достижения коммуникативно-прагматического эффекта» и может рассматриваться как разновидность художественного перевода (Горшкова 2007: 22). Его цель заключается в создании адекватной «...межъязыковой эстетической коммуникации путем интерпретации исходного текста, реализованной в новом тексте на другом языке» (Оболенская 2009: 108).

Для осмысления роли концепции культурного переноса при переводе кинотекста также важно обратить внимание на "Kombination kultureller Faktoren" (совокупность культурных факторов), которые создают особые трудности для переводчиков (Schreiber 1998: 151). В данном случае речь идет о микро- и макроструктурных единицах текста, подвергающихся культурным изменениям.

Кинотекст представляет собой сложное поликодовое образование, которое воспринимается только в единстве своего вербального, визуального и звукового воплощения. В то же время все его три составляющие содержат имплицитную информацию, обусловленную как самим национальным языком и культурой, так и намерениями автора, который осознанно ссылается в тексте на значимые для конкретного зрителя «языковые, литературные и социально-исторические факты» (Снеткова 2009: 12). Таким образом, в качестве макроструктурных компонентов кинотекста выступают его функционально-прагматические характеристики, а также экстралингвистический контекст (ситуации и условия, характерные для той среды, в которой кинопроизведение было создано). К его микроструктурным элементам относятся культурно-значимые/культурно-специфические единицы языка, несущие дополнительную коммуникативную нагрузку, т.е. сочетающие в себе информативную составляющую (передача общего смыслового содержания сообщения) и «(социо)культурную коннотацию» (Бавдинев 2005, Воркачев 2000, Телия 1998). В рамках культуры-отправителя данные единицы передают информацию, отражающую художественные, интеллектуальные, социальные и духовно-нравственные ценности. На уровне культуры-рецептора часто наблюдается несоответствие или даже противоречие языковому и этнокультурному мировоззрению адресата. Очевидно, что при интеграции в иную этносреду культурно-значимая информация нуждается в адаптации/локализации.

\section{3. ЛОКАЛИЗАЦИЯ В КИНОДИСКУРСЕ}

В последние годы теория локализации (Localization Studies) приобрела популярность в профессиональных переводческих кругах. В некоторых случаях этот термин трактуется как особый вид перевода, но зачастую подменяет собой данное понятие. Подробное рассмотрение проблематики терминологического статуса понятия «локализация» и его отношение к понятию «перевод» не входит в перечень основных задач данного исследования. Однако авторы статьи считают 
целесообразным обозначить суть данного явления и описать специфику локализации как разновидности адаптивного транскодирования в рамках сравнительносопоставительного анализа оригинальных названий французских кинофильмов и их переводных/локализированных вариантов.

В отечественной и зарубежной лингвистике термин «локализация» понимается как важная часть переводческого процесса, включающего в себя набор практик и техник адаптации оригинального текста для соответствия новой лингвосреде (Аносова 2014, Ачкасов 2016, Борисова 2018, Гарбовский 2004, Гудков 2003, Зинкевич 2018, Матвеев, Колосов 2016, Латышев 2000, Масленникова 2014, Климзо 2006, Сдобников 2019, Эко 2006, Hartley 2009, Gambier 2016, Leonardi 2011, Руm 2011, Venuti 1995). При этом речь идет не просто об упрощении ИТ для неподготовленной целевой аудитории, а об «обеспечении естественности» перевода, его структурно-содержательной и прагматической эквивалентности 5 . Иными словами, локализация - это прагматическая адаптация или «текстуализация интенций» (Латышев 2000: 46), нацеленная на построение эффективной коммуникации с представителями конкретной локальной культуры.

Коммуникативный акт в кинодискурсе представляет собой совокупность «вербальных, паравербальных и экстравербальных сигналов» (Kelz 2000: 249). Каждый из них имеет свою специфику в рамках того или иного этнокультурного пространства. Соответственно, при переносе в другую языковую и культурную плоскость эти сигналы могут нести «либо нулевое, либо искаженное значение» (Зинкевич 2018: 136). Для достижения максимальной результативности в процессе межкультурной кинокоммуникации реципиенту необходимо обладать межкультурной компетенцией на языковом, культурном и коммуникативном уровнях. Информация не просто передается зрителю и воспринимается им как некая данность, но претерпевает ряд серьезных трансформаций. Транслируемая информация заново воссоздается в сознании реципиента «с учетом его собственных когнитивных механизмов» (Гудков 2003: 21). Таким образом, локализация кинотекста предполагает взаимодействие как двух языков, так и двух картин мира, отражающих специфическое восприятие реальности (Мазлумян 2009: 83). В этой связи важное значение приобретает коммуникативная эквивалентность текста, пересекающаяся с концепциями функциональной и динамической эквивалентности Ю. Найды (Nida 1964, 1969), скопос-теорией К. Райс и Х. Вермеера (Reiß, Vermeer 2013) и Лейпцигской школы переводоведения (Jäger 1975; Kade 1981; Neubert 1973).

Современные практики локализации в киноиндустрии основываются на методах дискурсивного анализа и акцентируют внимание на адресате сообщения, который воспринимается как активный участник коммуникативного акта. Речь идет о прагматической адаптации текста, т.е. «о внесении некоторых поправок на социально-культурные, психологические и другие различия между получателями оригинального и переводного текста» (Эко 2006:139). Кроме того, локализация кинотекста предполагает воссоздание в новой лингвокультурной среде релевантной коммуникативной ситуации с учетом цели перевода ("translation

\footnotetext{
${ }^{5} \mathrm{http} / / /$ www.translators-union.ru.
} 
brief" / переводческое задание), потребностей и ожиданий реальных или предполагаемых получателей переводного текста (ПТ), «способа использования переводного текста в рамках предметной деятельности потребителей перевода» (Nord 2005: 9-10, Сдобников 2019). Очевидно, что данный подход выходит за рамки семантических и синтаксических стратегий, характерных для классического переводоведения, и смещает вектор на экстралингвистические факторы.

Принимая во внимание вышесказанное отметим, что при локализации иноязычного кинопродукта важно создать материал, не искажающий исходного замысла автора, и адекватно передать прагматические интенции, заложенные в структуру и содержание текста применительно к актуальной коммуникативной ситуации. В целом локализация как совокупность различных техник и практик адаптации снижает риск коммуникативного сбоя и прагматического несоответствия ИТ и ПТ.

\section{4. КИНОЗАГОЛОВОК: ЛИНГВИСТИЧЕСКИЕ И ФУНКЦИОНАЛЬНЫЕ ОСОБЕННОСТИ}

Название фильма - это многогранная языковая единица. С одной стороны, кинозаголовок обладает целостностью и некоторой автономностью по отношению ко всему произведению. Название может появиться еще до выхода картины в прокат, «будоража умы, вызывая определенные ассоциации, желание просмотра или абсолютное внутреннее отторжение у потенциального зрителя» (Горшкова 2014: 26). С другой стороны, оно не может дистанцироваться от образносмыслового содержания фильма, частью которого является. Фильмонимы вызывают научный интерес не только с позиций лингвистики (структурно-семантические и функционально-прагматические особенности), но также и в аспекте переводоведения и межкультурной коммуникации, если речь идет об иноязычном кинопроизведении. Переводные кинозаголовки демонстрируют «...глубинные связи означаемого и означающего, обусловленные культурной спецификой» (Александрова 2017: 1191), служат яркой иллюстрацией современных языковых процессов, отражающих актуальную политическую, экономическую и социальную ситуацию в мире. Для того, чтобы выявить стратегии перевода названий иноязычных фильмов, необходимо раскрыть сущность фильмонима как семиотической единицы и описать его особенности.

В лингвистике наблюдается общность подходов к анализу названий художественных фильмов и к заголовкам/заглавиям ${ }^{6}$, которые, как любые речевые произведения, рассматриваются с точки зрения синтаксиса, семантики (связанность и цельность содержательных параметров текста) и прагматики (реализация авторской интенции) (Крылова 2006: 218). Заглавие принято считать подсистемой текста, которая выполняет роль посредника между вертикальным контекстом (интертекстуальность) и адресатом, воспринимающим сообщение сквозь призму

\footnotetext{
${ }^{6}$ Некоторые исследователи противопоставляют термины «заголовок» и «заглавие»: заголовок имеет отношение к текстам СМИ и научной периодике, заглавие - к художественными произведениями. В данной статье данные термины используются как синонимичные.
} 
своего когнитивного опыта и эмоционально-ценностных установок. Соответственно, создание заголовка предполагает ориентацию на фоновые знания как автора, так и его целевой аудитории, а также соотнесенность названия с первичным поликодовым текстом и визуальным рядом (Александрова, Николаева 2016, Васильева 2006, Горшкова 2014). При передаче образного-смыслового содержания кинофильма именно название позволяет создать в сознании реципиента представление о концепте данного произведения. О.Ю. Богданова определяет заглавие как важнейший семантико-композиционный элемент художественного текста, «смысловой узел, замыкающий в себе последовательно переходящие друг в друга виды связи» (Богданова 2008: 4). Заголовок ретроспективно раскрывает замысел автора и не совпадает «на входе в текст и на выходе из текста» (Там же: 14). На начальном этапе (при прочтении названия) происходит знакомство с малой частью содержания. Далее в процессе просмотра или после него зритель получает впечатления, позволяющие переосмыслить заголовочный текст и (возможно) интерпретировать его иначе. На финальной стадии общее представление о произведении и личные впечатления сохраняются в памяти адресата на уровне ассоциативной связи с названием. Очевидно, что заголовки относятся к стилистически сильным позициям текста и реализуют «максимальную коммуникативную нагрузку» (Тураева 1988: 52). Как правило, они характеризуются лаконичностью, эмоциональностью, простым и легким языком для быстрого восприятия и запоминаемости информации.

Принимая во внимание неразрывную связь фильма и его названия, отметим, что последнее выполняют определенный функционал. Помимо номинативной, информативной, коммуникативной и художественно-эстетической функций, присущих всем заголовочным текстам, фильмонимы также осуществляют аттрактивную, рекламную и воздействующую функции. В современной киноиндустрии особое значение приобретают аттрактивная и рекламная функции. Они реализуются до просмотра, когда потенциальный зритель сталкивается с важным выбором - смотреть фильм или нет. Например, опрос информационно-аналитической службы компании «Яндекс» показал, что 76,7\% российских респондентов начинают читать синопсис киноленты, только если им понравилось название фильма и оформление афишы/постера.

Степень связанности заголовка с целостным кинотекстом, его идейно-образным содержанием, а также лексико-семантические и функционально-прагматические характеристики - это те параметры, которыми не следует пренебрегать при переводе и адаптации кинопродукта к иной лингвокультуре.

\section{5. СРАВНИТЕЛЬНО-СОПОСТАВИТЕЛЬНЫЙ АНАЛИЗ ОРИГИНАЛЬНЫХ НАЗВАНИЙ ФРАНЦУЗСКИХ КИНОФИЛЬМОВ И ИХ ПЕРЕВОДНЫХ/ЛОКАЛИЗИРОВАННЫХ ЭКВИВАЛЕНТОВ}

Интерпретация художественных фильмов и адаптация всех его составляющих под новую лингвокультуру значительно усложняется, так как, помимо автора и зрителя, в этот процесс включается переводчик или же целый переводческий коллектив, обладающий различным уровнем профессионализма, собственными 
фоновыми знаниями, эмоционально-ценностными ориентирами, вкусовыми предпочтениями, чувством и стилем языка. Даже на этапе работы с малыми формами вербальной части кинотекста (заголовок или слоган, если таковой имеется) переводчик привносит собственное понимание языковой ситуации, персонажей, событий, а зачастую, и авторского замысла в целом. Кроме того, над переводчиком стоит организация-заказчик, которую в первую очередь интересует финансовый аспект, т.е. количество проданных билетов на киносеанс.

Сравнительный анализ оригинальных французских названий и их переводных эквивалентов показал, что в процессе декодирования фильмонимов на русский язык используются различные стратегии: прямой, дословный перевод; перевод с трансформацией (опущение ключевых слов или их расширение); перевод с лексико-семантической, грамматической или комплексной трансформацией; перевод с экспликацией/компенсацией; вольный перевод. Корректное определение особенностей и характера каждой конкретной коммуникативной ситуации обозначает цель перевода и помогает переводчику выбрать соответствующую данной цели стратегию (Sdobnikov 2011: 1450).

Перевод кинозаголовков можно рассматривать как удачный или неудачный (адекватный/неадекватный), опираясь на различные критерии: эстетические, семантические, стилистические, лингвокультурологические и функциональнопрагматические. В рамках данного исследования при анализе степени лингвокультурной адаптации названий французских художественных фильмов был проведен опрос, в котором приняли участие 120 человек в возрасте от 18 до 35 лет, владеющие французским языком на уровне В2-C1 и посмотревшие фильмы, названные в анкете. Респондентам было предложено оценить перевод на русский язык 87 фильмонимов.

\section{1. ПРЯМОЙ ПЕРЕВОД}

В процессе декодирования названий художественных фильмов наиболее простым, точным и адекватным считается прямой перевод. Современные французские кинемаграфисты в своих работах уделяют пристальное внимание характерам и судьбам отдельных личностей. Сюжеты многих французских фильмов описывают повседневную жизнь людей, их стремления, ценности, цели, восприятие действительности и взаимоотношения с окружающими. Анализ эмпирического материала показал, что прямой перевод регулярно применяется, если кинозаголовок состоит из имени собственного, географического названия или включает в свой состав лексемы, обозначающие профессию, семейное положение, социальный статус персонажа/персонажей, а также слова с прямым или универсальным метафорическим значением. Оригинальные названия, как правило, состоят из $1-2$ слов. Лаконичность ИТ изначально не предполагает использования длинных и сложных конструкций в ПТ. В большинстве случаев прямой перевод позволяет осуществить полноценную передачу исходного замысла автора. Верность оригинального названия переводному обусловлена тождеством взаимоэквивалентных единиц по структурным и содержательным параметрам, а также легкостью воспроизведения имен собственных (антропонимов/топонимов) при помощи транскрипции. 
Прямой перевод французских фильмонимов, состоящих из национальных антропонимов, топонимов и лексем с прямым и универсальным значением

\begin{tabular}{|l|l|c|l|}
\hline Оригинальное название & \multicolumn{1}{|c|}{ Жанр } & Год выпуска & Переводное название \\
\hline Jean-Philippe & Музыкальная комедия / фэнтези & 2006 & Жан-Филипп \\
\hline Paulette & Комедия & 2012 & Полетта \\
\hline Le Petit Nicolas & Комедия & 2009 & Маленький Николя \\
\hline Alaska & Романтическая драма & 2015 & Аляска \\
\hline Marseille & Комедия & 2016 & Марсель \\
\hline Veuf & Драма & 2017 & Вдовец \\
\hline Comptable & Комедия & 2004 & Бухгалтер \\
\hline Danseuse & Драма-биография & 2016 & Танцовщица \\
\hline Ma mère & Драма-мелодрама & 2004 & Моя мать \\
\hline Demi-soeurs & Комедия & 2018 & Сводные сестры \\
\hline Une vie & Драма & 2016 & Жизнь \\
\hline La Fidélité & Драма & 2000 & Верность \\
\hline
\end{tabular}

Национальные антропонимы/топонимы или лексемы, обозначающие философские категории, сами по себе способны выполнять аттрактивную, рекламную и перлокутивную функции. Как видно из таблицы 1, одним из превалирующих жанров современного французского кинематографа являются различные вариации драмы. По мнению Н.В. Бочарниковой, именно драматическое произведение наиболее точно описывает эмоциональные переживания индивида, и поэтому многочисленные драматические фильмонимы акцентируют внимание на личности персонажей, а «абстрактные названия фильмов побуждают зрителя к их просмотру» (Бочарникова 2012: 193). Французские имена считаются одними из самых красивых и мелодичных в мире, а для «русского уха» обладают особым магнетизмом. Французский язык традиционно отождествлялся в России с благородством и высокими чувствами. Не исключено, что французские антропонимы/ топонимы, выносимые в заголовочный текст, могут положительно повлиять на эмоциональный настрой реципиента и навеять приятные воспоминания.

Дословно также часто переводятся названия, состоящие из простого словосочетания или целого предложения.

Таблица 2

Прямой перевод французских фильмонимов, состоящих из словосочетания/предложения

\begin{tabular}{|l|l|c|l|}
\hline \multicolumn{1}{|c|}{ Оригинальное название } & \multicolumn{1}{|c|}{ Жанр } & \multicolumn{1}{|c|}{$\begin{array}{c}\text { Год } \\
\text { выпуска }\end{array}$} & \multicolumn{1}{|c|}{ Переводное название } \\
\hline Erreur de la banque en votre faveur & Комедия & 2009 & Ошибка банка в вашу пользу \\
\hline Tout ce qui brille & Комедия & 2010 & Все то, что сверкает \\
\hline L'homme qui voulait vivre sa vie & Драма & 2010 & $\begin{array}{l}\text { Человек, который хотел жить } \\
\text { по-своему }\end{array}$ \\
\hline Bienvenue à bord & Комедия & 2011 & Добро пожаловать на борт \\
\hline Vive la France & Комедия & 2013 & Да здравствует Франция! \\
\hline Le Transporteur: Héritage & Боевик & 2015 & Перевозчик: наследие \\
\hline Le divan de Stalin & Историческая драма & 2016 & Диван Сталина \\
\hline
\end{tabular}


Оригинальные и переводные названия помогают распознать жанр фильма. Их дословный перевод объясняется тем, что они не содержат никаких непереводимых культуроспецифических элементов. Однако в отдельных случаях переводной заголовок может быть точнее оригинального и отличаться от него по прагмалингвистическим функциям.

Например, название приключенческого боевика "Les voleurs" (2003, букв: Воры) было переведено как «Воровка». При переводе благодаря грамматическим возможностям языка-рецептора имя существительное утратило форму множественного числа и приобрело значение женского рода. Таким образом, переводная версия названия сообщает потенциальному зрителю о том, что главным персонажем картины является именно героиня, в то время как в исходном тексте сохраняется неопределенность. Названия «Воры» и «Воровка» вызывают разные эмоции и ассоциации.

Военная драма "Elle s'appelait Sarah" (2010) появилась на российских экранах под заголовком «Ее зовуm Capa». В данном примере заменяется временная форма глагола. В ИТ используется прошедшее незавершенное время (Imparfait), в ПТ настоящее. Это позволяет актуализировать события, происходящие в фильме и «воскресить» персонажа другой эпохи. При переводе синопсиса данной картины на русский язык также целенаправленно была исключена фраза, косвенно указывающая на выбор временной формы в оригинальном названии: "La vérité issue du passé a parfois un prix dans le présent...” («Правда прошлого порой имеет значение в будущем...»).

Заголовок французской комедии "Les Femmes du 6e étage" (2010) был переведен дословно «Женщзины с 6-го этажа», несмотря на тот факт, что русские и французы по-разному считают этажи в домах: французский 6-й этаж - это русский 7-й. Однако данный факт не имеет значения, так как не влияет на связь названия с жанром и содержанием фильма и не искажает авторского замысла. Большая часть россиян не имеет представления о специфике числительных во французском языке.

\section{2. ПЕРЕВОД С ТРАНСФОРМАЦИЕЙ}

При локализации французских названий для русскоязычной аудитории приблизительно 58\% фильмонимов претерпели различные синтаксические и лексикосемантические изменения, которые привели к частичному/полному несоответствию ИТ и ПТ. Рассмотрим использование данных модификаций и степень адекватности перевода на конкретных примерах.

\subsection{1. СИНТАКСИЧЕСКИЕ ТРАНСФОРМАЦИИ}

ИТ: La guerre est déclarée (2011)

ПТ: Я объявляю войну

Мелодрама рассказывает о борьбе отца за жизнь своего маленького сына, который болен раком. Переводчик заменяет пассивную конструкцию оригинального названия (букв: Война объявлена) на активную, включая в его состав личное местоимение — «Я». Употребление местоимения 1-го лица позволяет превратить 
изначально безличный и анонимный текст в доверительный, создать эффект причастия и соучастия.

ИТ: Protéger et servir (2009)

ПТ: Служить и защищщать

Комедия повествует о двух нерадивых и взбалмошных полицейских, которым пришлось противостоять опасным преступникам, планирующим серию терактов в Париже. При передаче названия меняется порядок слов. Подобная перестановка представляется более благозвучной и логичной для русскоязычной аудитории. В России служение родине уже подразумевает ее защиту. Однако в данном случае наблюдается некоторый разрыв заглавия с жанрово-тематической направленностью картины. В восприятии российского зрителя словосочетание «Служить и защищать» ассоциативно перекликается с такими национально-прецедентными высказываниями, как «Служу Отечеству», «Служу Родине», «Есть такая профессия - Родину защчищать». Возможно, что столь пафосный заголовок, апеллирующий к чувству патриотизма, не совсем уместен для комедии. Название фильма дает не вполне верное представление о содержании фильма, создает эффект обманутого ожидания и нарушает его образно-смысловую составляющую. Об этом также свидетельствуют мнения респондентов: 87 из 120 участников проведенного опроса отметили, что ожидали увидеть военный или военно-исторический фильм, а не полицейскую комедию.

\subsection{2. ЛЕКСИКО-СЕМАНТИЧЕСКИЕ ТРАНСФОРМАЦИИ}

\section{Частичная замена}

ИТ: Il etait une fois un flic... (2001)

ПТ: Жил-был полицейский

В центре сюжета - опытный и отважный комиссар полиции, вступивший в неравную схватку с мафиозными структурами. При переводе названия лексема flic, относящаяся к сниженному регистру речи и обладающая ярко-выраженной экспрессивной окраской, заменяется на нейтральную - полицейский. В словарях Robert, Larousse, Hachette лексема "flic" сопровождаются стилистическими пометами “fam.” (разговорный), “рор.” (просторечный), “arg.” (арготический). Русским стилистическим эквивалентом является слово мент, от которого локализаторы отказались по ряду причин. Прежде всего замена обусловлена тем, что в современном сознании русскоязычной аудитории данная лексема имеет неодобрительно-оценочное значение, а для сотрудников правоохранительных органов оно является оскорбительным. Главный герой картины - личность положительная, поэтому употребление слова мент могло бы исказить образ персонажа и общую смысловую направленность картины.

ИТ: Je te survivrai (2013)

ПТ: Я закопаю тебя

Буквальный перевод заглавия этой французской драмы/комедии - «Я тебя переживу». Переводчик прибегает к стилистической трансформации, заменяя нейтральный глагол на более броский и эмоциональный эквивалент. Эмоцио- 
нальность также усиливается за счет инверсии глагола и личного местоимения «тебя». Переводной заголовок более приближен к содержанию фильма, нежели его оригинал. По сюжету главный герой оказывается на дне глубокого колодца. Об этом знает только соседка, которая его ненавидит. Такие высказывания, как Я тебя закопаю, Я тебя живьем закопаю и т.д., относятся к разговорному стилю речи, хорошо освоены русским сознанием и даже входят в русский пословичный фонд. Например: Я тебя, как француза, живьем закопаю (Даль 1989). Безусловно, яркое название привлечет внимание зрителей, особенно молодежной аудитории. Однако при переводе несколько смещается образно-смысловая сущность картины. Оригинальное название фильма акцентирует внимание на стремлении главного героя выжить любой ценой, переводное название подчеркивает его намерение отомстить своей обидчице. Больше половины участников опроса (74) отметили эмоциональную насыщенность заголовка и посчитали его переводную версию адекватной и креативной, сочетающейся с драматическо-комедийной направленностью фильма.

ИТ: Le temps qui reste (2005)

ПТ: Время прощзания

Драма известного французского режиссера Франсуа Озона была впервые продемонстрирована публике на Каннском фестивале в категории «Особый взгляд». Это история о модном фотографе нетрадиционной ориентации по имени Ромэн, который узнает о том, что из-за онкологического заболевания жить ему осталось несколько месяцев. Оригинальное название картины (букв: «Оставшееся время») было подвергнуто лексико-грамматической трансформации. Замена двух исходных элементов ( “qui reste”) на лексему прощзание придало картине иное, неверное звучание. Это связано с тем, что в русской культуре концепт «прощание» обладает драматизмом, который отсутствует в иноязычных эквивалентах. В первую очередь прощзание - это сильное эмоциональное переживание, связанное с потерей родных и близких. Русский человек осмысляет прощание не как закономерный этап своей жизни, без которого невозможен новый виток, а «как неподвластную ему мучительную ситуацию, после которой он предвидит нежелательное для него изменение положения» (Лассан 2015: 17). Как писал поэт Н. Заболоцкий, «Прощуание! Скорбное слово!». Однако в данной киноленте, несмотря на трагичность ситуации, никто не скорбит - ни главный герой, ни окружающие его люди. Ромэн достойно принимает страшное известие. Он не пускается во все тяжкие, не пытается переосмыслить прошлое или исповедаться во всех своих грехах, просто хочет понять, что еще успеет сделать. Остальные персонажи тоже ведут себя спокойно. Бабушка принимает новость о скорой смерти внука с долей мрачной иронии; эгоистичный молодой любовник думает о себе и своей дальнейшей жизни; сестра, которая долго не общалась с братом, не знает, как с ним помириться и стоит ли это вообще делать только из-за его смертельной болезни. В итоге Ромен соглашается на просьбу бездетной пары стать биологическим отцом их ребенка. По замыслу режиссера, главный герой не прощается, он дает начало новой жизни. Таким образом, мы видим, что переводная версия названия не отвечает критериям переводческой адекватности, так как создает заведомо неверное представление 
о содержании картины, не отражает его многогранности, «сужая рамки образасмысла» (Горшкова 2014: 34). Участники опроса (89 человек) отрицательно высказались относительно переводного заголовка, отметив несочетаемость названия с идей фильма и режиссерским посылом.

\subsection{3. Добавление}

ИТ: Les profs (2013)

ПТ: Безумныле преподы

Сюжет этой молодежной комедии (букв: «Преподыл») рассказывает о французском лицее. Его учащиеся - неуправляемые хулиганы, неспособные сдать выпускные экзамены. Руководство учебного заведения принимает решение пригласить на работу «нестандартных» преподавателей, способных быть на одной волне со своими учениками. В название был добавлен эпитет безумныле, характеризующий главных действующих лиц. Употребление лексем, характерных для молодежной речи, сочетается с жанровой принадлежностью фильма и привлекает внимание зрителей этой возрастной категории. В синопсисе картины при описании персонажей локализаторы продолжают использовать прием добавления разговорных и стилистических единиц в оригинальный текст. Например: “....sept professeurs aux méthodes atypiques” / «десанm сумасбродных преподов»; “...Éric, adepte des exercices dangereux"/ «Эрик, брутальный качок»; "Polochon, idolâtrant Napoléon”/ «Полошон, безобидный отморозок в костюме Наполеона».

Отметим, что картина собрала хорошие кассовые сборы как во Франции, так и в России. Два года спустя был выпущено ее продолжение:

ИТ: Les profs 2 (2015)

ПТ: Безумные преподы: Миссия в Лондоне

Локализатор добавляет своего рода переводческий комментарий/пояснение, указывающий на место, где происходят основные события. При этом сохраняется трансформация, примененная при переводе названия первой части киноленты (“Les profs” / «Безумные nреподbl»), которая имела успех у российского зрителя. По мнению большинства респондентов (89 человек), переводное название звучит ярче и интереснее оригинального.

ИТ: Derrière les Murs (2011)

ПТ: Кошмар за стеной

В данном случае наблюдается расширение информации о содержании фильма и его жанровой принадлежности посредством ввода ключевого слова кошмар в состав переводного заголовка. Буквальный перевод названия «З $а$ стенами» представляется слишком абстрактным, не отражает жанра произведения (триллер) и не реализует функцию антиципации, т.е. «предвкушения событий» (VelevaBorisova 1993).

В целом, включение интерпретирующих языковых единиц в ПТ необходимо не только для идентификации жанра или «образа-смысла» произведения (Горшкова 2014), но и для формирования в сознании реципиента определенных кон- 
цептов, гарантирующих востребованность и коммерческую успешность картины. Участники опроса (105 человек) считают переводное название, приведенное выше, логичным, более информативным и адекватным.

\subsection{4. Опущение}

ИT: OSS 117: Le Caire, nid d'espions (2006)

ПT: Агент 117

Адаптируя заглавие этой приключенческой комедии для российского проката, переводчик исключает из названия вторую часть («...Каир, гнездо шиионов») как наименее важную со смысловой точки зрения. При локализации также заменяется специальный позывной главного героя (OSS) на слово Агент. Таким образом переводчик создает ассоциацию со знаменитым Агентом 007 - Джеймсом Бондом. Это, безусловно, позволило привлечь в кинозалы не только любителей боевиков, шпионских детективов, но и многочисленных поклонников «Бондианы». Данный прием, в первую очередь, ориентирован на реализацию коммерческой и рекламной функций, но при этом не снижает степени адекватности ПТ. Положительную оценку данный переводный заголовок получил от всех участников анкетирования.

\subsection{5. Вольный перевод}

ИТ: “Zizou” (2017)

ПТ: «Зидан: легенда навсегда»

Документально-биографическая лента (букв: «Зизу») вышла в российский прокат с гораздо более длинным и замысловатым названием: переводчик использовал фамилию главного героя (Зидан) и определил значимость его личности («легенда навсегда»). В картине рассказывается о жизни и яркой спортивной карьере французского футболиста Зинедина Зидана, которого во Франции ласково называют Зизу. Переводчик отказался от прямого перевода, так как опирался на фоновые знания целевой аудитории. Зидан - мировая знаменитость, но далеко не факт, что российская публика знает его «домашнее прозвище». Кроме того, использовав лексему легенда, локализатор определенным образом расширил возможности интерпретации содержания названия и фильма. С первых минут (даже если реципиент не интересуется спортом и не знает имена известных спортсменов) становится понятно, что речь пойдет о выдающейся личности. Интересно, что в ходе опроса 64 респондента провели параллель с русским фильмом «Легенда № 17», повествующем о знаменитом советском хоккеисте Валерии Харламове.

ИT: Populaire (2012)

ПТ: Любовь на кончиках пальщев

Действие происходит в конце 50-х годов прошлого столетия во французской провинции. Тихая и спокойная жизнь молодой девушки по имени Роза меняется, когда она устраивается на работу машинисткой. Начальник (Луи) обучает ее специальному методу слепого набора. Роза попадает на международный конкурс по скоростной машинописи и выигрывает его. Однако любовь к Луи для нее 
важнее карьерных успехов. Роза работает на печатной машинке "La Populaire" (модель известного бренда “Јapy”). Именно название данной марки послужило основой исходного текста. Очевидно, что в данном случае прямой перевод невозможен, так как название этой французской марки незнакомо целевой аудитории. Заголовок, с которым фильм выходит в русском прокате, содержит выразительную метафору, явно намекающую на жанр фильма (романтический/ лирический/любовный). В то же время присутствует аллюзия на профессию главной героини. Метафоризация способствует возникновению у зрителя стремления к интерпретации, что побуждает его к просмотру произведения. По мнению всех 120 участников анкетирования, переводное название звучит лучше оригинального.

ИТ: Un episode neigeux (2017)

ПТ: А снег идет...

Буквальный перевод авторского цикла лирических короткометражек (3 истории) о жизни обычных парижан, справляющихся с непогодой — «Снежный эпизод». Неожиданные сильные осадки в столице Франции вызвали у ее жителей различные эмоции. Дети радуются и играют в снежки. Взрослые проклинают снегопад из-за аварий/пробок на дорогах. Особо впечатлительные граждане запасаются теплой одеждой и продовольствием, опасаясь начала ледникового периода. А влюбленная пара катается на коньках, любуясь падающими снежными хлопьями. При локализации кинозаголовка переводчик использовал аллюзию, отвечающую фоновым знаниям рядового российского зрителя. Косвенный намек на известную новогоднюю песню «А снег идет, а снег идет... И все вокруг чего-то ждет...» обогащает абстрактное оригинальное название и все кинопроизведение знаниями и опытом культуры-рецептора. Впервые песня прозвучала в кинофильме «Карьера Димы Горина» (1961) в исполнении певицы Майи Кристалинской. Однако даже 60 лет спустя она продолжает оставаться популярной, часто транслируется по радио и телевидению и фигурирует в репертуаре многих современных вокалистов (Жанна Агузарова, Глюкоза). Творческий подход к переводу также позволил повысить эмоционально-оценочное содержание кинотекста и привлечь внимание разновозрастной зрительской аудитории. Креативность переводного названия была высоко оценена в ходе проведенного анкетирования (120 положительных отзывов).

ИТ: Joséphine (2013)

ПТ: Хочу как Бриджит

В комедии/мелодраме рассказывается о молодой девушке, фигура которой далека от современных модных стандартов. Именно этот факт, по ее мнению, является главной причиной отсутствия у нее личной жизни. Устав от безуспешных попыток найти свою любовь и сочувствие со стороны окружающих, девушка придумывает роман с бразильским хирургом. Эта безобидная фантазия превращает ее жизнь в приключение со счастливым концом. При локализации было полностью заменено оригинальное название, в состав которого входил антропоним Жозефина. Переводной заголовок картины представляет собой явную аллюзию 
на фильм Bridget Jones's diary («Дневник Бриджит Джонс»), героиня которого переживает схожие проблемы. Эта комедия долгое время было лидером российского проката. В данном случае личностная (ономастическая) аллюзия несет в себе не только память о произведении, но и представления об авторской позиции, а также оценку главных действующих лиц. Цель заключается в том, чтобы зритель заметил сходство с предыдущей историей и провел задуманную локализатором аналогию, т.е. принял решение посмотреть картину, базируясь на своем предыдущем положительном опыте. Однако по отзывам респондентов переводное название с использованием стилистического приема аллюзии себя не оправдало. Они не увидели ни похожей сюжетной линии, ни сходства между образами главных героинь. Единственный общий признак - это их немодельная внешность. Следовательно, можно признать факт неудачной адаптации кинозаголовка, несмотря на то, что прагматическая и рекламная функции были реализованы в полной мере: локализаторы обеспечили фильму высокие кассовые сборы в первые дни проката, но через некоторое время рейтинг картины значительно упал.

ИТ: Demain tout commence (2016)

ПТ: $2+1$

При локализации названия этой французской мелодрамы, так же как и в предыдущем примере, произошел эффект обманутых ожиданий из-за ложной аллюзии. Буквальный перевод («Все начнется завтра») заменили, руководствуясь исключительно финансовыми целями и задачами. Главную роль в картине исполняет французский актер Омар Си, ранее снимавшийся в фильме "Intouchables" (букв: «Неприкасаемые»; русское переводное название - «1+1»). Кинолента имела огромный успех на российском рынке. Задумка заключалась в том, чтобы создать в сознании целевой аудитории четкую ассоциацию с ранее успешным продуктом. В результате большая часть потенциальных зрителей восприняла картину « $2+1 »$ как продолжение истории полюбившихся им героев из фильма-предшественника. В действительности оказалось, что между эти двумя произведениями нет никакой связи. Омар Си играет совершенно другого персонажа (с другим именем, биографией, характером и т.д.); сюжетная линия рассказывает о переменах в его жизни, произошедших в связи с неожиданно обретенной дочерью-младенцем. Разочарование публики из-за рекламного трюка со стороны локализаторов отрицательно повлияло не только на общее восприятие киноленты, но и на ее успешность в прокате (94 негативных отзыва наших информантов о несоответствии названия содержанию).

ИТ: Bienvenue chez les Ch'tis (2010)

ПТ: Бобро поржаловать!

В центре сюжета - начальник почтового отделения провинциального французского городка. Он готов на все, чтобы получить назначение на Лазурный берег. Однако в качестве наказания его отправляют в небольшой городок на севере Франции. В сознании большинства жителей юга Франции бытует стереотип, что север это ужасный ледяной край, а его обитатели - грубые мужланы, говорящие на непонятном языке. Однако к своему удивлению главный герой вскоре об- 
наруживает, что на севере очень красиво, там живут милые и душевные люди, а к необычному говору можно легко привыкнуть. Именно название местного диалекта “Ch'ti” (Шти), распространенного в регионе Нор-Па-де-Кале́-Пика́рдия (Nord-Pas-de-Calais-Picardie), обыгрывается в оригинальном названии. Буквальный перевод кинозаголовка - «Добро пожаловать к Шти», т.е. к жителям, изъясняющимся на этом наречии. Очевидно, что лексему «шти» невозможно было сохранить при адаптации названия ввиду ее национально-культурной обусловленности, абсолютно неизвестной и непонятной русскоязычной публике. В переводной версии используется прием каламбура, построенного на умышленном шуточном искажении слов (Добро / Бобро; пожаловать/поржаловать). Каламбурная форма позволила локализаторам ${ }^{7}$ не просто придать тексту особую выразительность, эмоциональность и занимательность, усиливающие сатирический эффект, но и сосредоточить внимание аудитории на главной мысли произведения - сломать стереотипные представления, в том числе и лингвистические. Режиссер картины в одном из своих интервью сказал, что смысл его произведения очень точно определяет пословица: “Dans ch'nord tu pleures deux fois: eul première in narrivant, et l'chegonde, pasqué tu veux pu apartir"8 — «Чужак на севере плачет дважды: когда приезжает и когда уезжает» ${ }^{9}$. Как на французском, так и на российском рынке, фильм получил высокую зрительскую оценку и собрал рекордные кассовые сборы. По данным ресурса «Кинопоиск», за первую неделю проката в России картину посмотрели более 20 миллионов человек ${ }^{10}$. Участники нашего анкетирования отметили, что название фильма первоначально вызвало удивление (78 человек) и непонимание (42 человека). Однако респондентам изначально была понятна комедийная направленность киноленты. Осознание сути каламбура, использованного в заглавии, пришло после просмотра всего произведения. По мнению 100\% респондентов, данную переводческую адаптацию следует считать удачной. Также отметим, что этот фильм в определенной степени обогатил культуру-рецептор. Многие участники анкетирования озвучили желание поближе познакомиться с историей и традициями севера Франции.

\section{6. ЗАКЛЮЧЕНИЕ}

Подводя итоги проведенному исследованию, выделим следующие моменты.

- При локализации кинозаголовков с французского языка на русский применяются разнообразные стратегии: транслитерация, прямой (дословный) перевод, грамматические и лексико-семантические модификации, полная замена исходного материала. На первый взгляд, мы не видим радикальных отличий от стратегии передачи других видов текста. Однако при переводе кинозаголовков наблюдается своя специфика, в большей степени продиктованная экстралингвистическими факторами. Для выбора стратегии важно адекватно оценить характер и особенно-

7 В процессе локализации названия участвовал российский актер и автор комейдиных скетчей - Андрей Бочарников (Бочарик).

8 Пословица написана на диалекте «Шти».

9 https://www.vokrug.tv/product/show/bienvenue_chez_les_chtis/.

10 https:/www.kinopoisk.ru/film/bobro-porzhalovat-2008-391735/. 
сти коммуникативной ситуации, в которой реализуется текст. В процессе локализации необходимо сохранить связанность кинозаголовка с сюжетом, композицией, жанром и идейно-образным содержанием.

- При невозможности использовать стратегию прямого перевода с сохранением структурно-семантических особенностей в ИТ за основу берется жанровая направленность кинопроизведения, обуславливающая выбор соответствующих лексико-стилистических средств. Если в состав названия включены непереводимые этнокультурные элементы, то наиболее частотной оказывается стратегия перевода с трансформацией или вольный перевод. Трансформации кинозаголовков при переводе на русский язык чаще всего осуществляются по общему лексикограмматическому принципу. Полная замена оригинального названия сопряжена с высоким риском коммуникативной неудачи. Однако вольный перевод вполне допустим и даже предпочтителен, если речь идет о локализации названий кинопроизведений, относящихся к «легким жанрам» (комедии, любовные мелодрамы, мультфильмы) и не затрагивающих серьезных философских вопросов. Вольный перевод в большей степени ориентирован на реализацию рекламно-коммерческих целей.

- Большую часть переводов названий французских художественных фильмов на русский язык, включенных в корпус исследования (87 фильмонимов), можно считать удачными (адекватными). По результатам опроса 79\% переводных кинозаголовков были признаны адекватными. В некоторых случаях переводное название получило более высокую оценку, чем оригинальное (12\%). Серьезной критике подверглись $21 \%$ кинозаглавий. Неприятие перевода было в большей степени обусловлено либо неудачной трансформацией, либо неоправданной заменой, которые нарушают жанр, сюжетную линию и идейно-эстетическое содержание картины.

- Локализация иноязычной кинопродукции в условиях современного рынка - это коллективный процесс, в котором окончательное решение принимает не переводчик, а дистрибьютерская/прокатная кинокомпания. Очевидно, что эти два участника могут преследовать разные цели. Зачастую неудачная локализация фильмонима - это вина прокатчика, не услышавшего или не захотевшего услышать специалиста. Однако шанс быть услышанным есть всегда, и он напрямую зависит от степени убедительности аргументации переводчика.

(C) В.Е. Анисимов, А.С. Борисова, Г.Р. Консон, 2019

\section{ФИНАСИРОВАНИЕ И БЛАГОДАРНОСТИ:}

Публикация подготовлена при поддержке Программы РУДН «5-100». Авторы статьи благодарят студентов и аспирантов кафедры иностранных языков филологического факультета РУДН за участие в анкетировании, результаты которого внесли большой вклад в написание данной статьи.

\section{СПИСОК ЛИТЕРАТУРЫ / REFERENCES}

Ballard, Michel (2005). La traduction, contact de langues et de cultures. Arras: Artois Presses Université.

Bassnett, Susan (2005). Translation Studies. 3rd ed. London and New York, Routledge. 
Bastin, Georges L. (1990). L'adaptation, conditions et concept. Etudes traductologiques en hommage à Danica Seleskovitch. Paris: Lettres modernes, Minard, 215-230.

Boillat, Alain \& Cordonier, Laure. (2013). La traduction audiovisuelle : contraintes (et) pratiques. Entretien avec Isabelle Audinot et Sylvestre Meininger. Décadrages. Cinéma à travers champs. Dossier: le doublage, 23-24, 9-27.

Catteau, Jacques (2011). Un art de la métaphore filmique. Traduire en images, 41, 26-30.

Cranmer, Robin (2015). Introducing Intercultural Communication into the Teaching of Translation. Russian Journal of Linguistics, 19 (4), 155-174.

Espagne, Michel \& Werner, Michael (1987). La construction d'une référence culturelle allemande en France: genèse et histoire (1750 - 1914). Annales ESX, 42 (4), 969 — 992.

Espagne, Michel \& Werner, Michael (1988). Transferts. Les Relations interculturelles dans l'espace franco-allemand (XVIIIe et XIXe siècle). P.: Editions Recherches sur les Civilisations, 11-34.

Gambier, Yves (2016). Rapid and Radical Changes in Translation and Translation Studies. International Journal of Communication, 10, 887-906.

Gambier, Yves (2002). Circulez, il y a à voir... aspects multiformes de «l'adaptation» cinématographique // Identité, altérité, équivalence? La traduction comme relation: Actes du Colloque International tenu à l'ESIT les 24, 25 et 26 mai 2000. Paris : Caen: Lettres modernes Minard, $339-358$.

Gambier, Yves (2008). Recent developments and challenges in audiovisual translation research. Between Text and Image: Updating Research in Screen Translation. Amsterdam; Philadelphia: John Benjamins Publ. Co., 11-35.

Hartley, Tony (2009). Technology and translation. The Routledge Companion to Translation Studies. L.; N.Y.: Routledge, 106-127.

Jäger, Gert (1975). Translation und Translationslinguistik. Halle (Saale): VEB Max Niemeyer.

Jullier, Laurent (2012). Analyser un film. De l'émotion à l'interprétation. Paris: Flammarion.

Jurt, Joseph (2007). Traduction et transfert culturel. De la traduction et des transferts culturels. Paris, 92-111.

Kade, Otto (1981). Probleme des übersetzungswissenschaftlichen Textvergleichs. Leipzig: VEB Enzyklopädie (Übersetzungswissenschaftliche Beiträge 4).

Katan, David (2009). Translation as Intercultural Communication. The Routledge Companion to Translation Studies. Revised edition. Jeremy Munday (ed.). London, New York: Routledge.

Kelz, H.P. (2000). Interkulturelle Kommunikation und Wirtschaftsdeutsch-Didaktik. Das Wort. Germanistisches Jahrbuch '00-01 GUS. Moskva: Metatext, Ltd.

Leinen, Franc (2007). Limites et possibilités du transfert culturel. L'exemple de la traduction allemande de L'Amour, la fantasia, d'Assia Djebar. De la traduction et des transferts culturels. Paris, $137-156$.

Leonardi, Vanessa (2011). Translating film titles: Linguistic skills, cultural awareness or marketing strategies? // Язык, коммуникачия и сочиальная среда. № 9, 180-201.

Nida, Eugene (1964). Toward a Science of Translating. With Special Reference to Principles and Procedures in Bible Translating. Leiden: Brill.

Nida, Eugene and Taber, Charles (1969). The Theory and Practice of Translation. Leiden: Brill.

Nord, Christiane (2005). Text Analysis in Translation. Theory, Methodology and Didactic Application of a Model of Translation-Oriented Text Analysis. 2nd ed. Editions Rodopi, Amsterdam New York.

Nord, Christiane (2019). Paving the Way to the Text: Forms and Functions of Book Titles in Translation. Russian Journal of Linguistics, 23 (2), 328 -343. doi: 10.22363/2312-9182-2019-232-328-343. 
Pym, Anthony (2011). What Technology Does to Translating. Translation and Interpreting, 3 (1).

Reiß, Katharina and Vermeer, Hans (2013). Towards a General Theory of Translational Action. Skopos Theory Explained / Translated from German by Christiane Nord. Manchester: St. Jerome Publishing.

Sdobnikov, Vadim (2011). Translation Strategy Revised: The Communicative-Functional Approach Journal of Siberian Federal University. Humanities \& Social Sciences, 4 (10).

Schreiber, Michael (1998). "Ubersetzungstypen und Ubersetzungsverfahren”. Mary Snell-Hornby, Hans G. Hönig, Paul Kussmaul and Peter A. Schmitt (eds). Handbuch Translation. Tuibingen: Stauffenburg, 151-154.

Schreiber, Michael (2007). Transfert culturel et procédés de traduction: l'exemple des realia. De la traduction et des transferts culturels. Paris, 185-194.

Thill, Beata (2007). "Défaire les cases": la langue et la traduction dans le transfert culturel. De la traduction et des transferts culturels. Paris, 195-217.

Valentini, Chiara (2011). La traduction des références culturelles dans le doublage pour le cinéma et la télévision: résultats d'une analyse empirique. Traduction et médias audiovisuels. Paris: Septentrion, 93-109.

Veleva-Borissova, Anna (1993). La théorie interprétative de la traduction et les titres. Paris: ESIT.

Venuti, Lawrence (1995). The Translator's Invisibility. L.; N.Y.: Routledge.

Александрова О.И., Николаева У.А. Стратегии перевода англоязычных фильмонимов на русский и испанский языки // Вестник Российского университета дружбы народов. Серия: Теория языка. Семиотика. Семантика. 2016. № 2. С. 113-122. [Aleкsandrova, Oksana, Nikolayeva, Uliana (2016). Traslation Strategies of Modern English Filmonyms into Russian and Spanish (the example of films released in 2008-2014). RUDN Journal of Language Studies, Semiotics and Semantics, 2, 113-122. (In Russ.)]

Александрова О.И. Оригинальные и переводные названия кинофильмов как особые функциональные единицы // Вестник Российского университета дружбы народов. Серия: Теория языка. Семиотика. Семантика. 2017. 8 (4). С. 1191-1199. [Aleкsandrova, Oksana (2017). Original and Translated Film Titles as Specific Naming Units. RUDN Journal of Language Studies, Semiotics and Semantics, 8 (4), 1191-1199 (In Russ.)] DOI: http://dx.doi.org/ 10.22363/2313-2299-2017-8-4-1191-1199.

Аносова Н.Э. Перевод в свете межкультурной коммуникации // Индустрия перевода. 2014. T. 1. C. 8-13. [Anosova, N.E. (2014). Perevod v svete mezhkul'turnoi kommunikatsii (Translation in Intercultural Communication). Industriya perevoda, 1, 8-13. (In Russ.)]

Ачкасов А.В. If the Mountain Won't Come... Translation Studies meets Localization // Журнал Сибирского федерального университета. Серия: Гуманитарные науки. 2016 Т. 9. № 3. C. 568-578. [Achkasov, A.V. (2016). If the Mountain Won't Come... Translation Studies meets Localization. Zhurnal Sibirskogo federal'nogo universiteta. Seriya: Gumanitarnye nauki, 9 (3), $568-578]$.

Богданова О.Ю. Заглавие как семантико-композиционный элемент художественного текста (на материале английского языка). М., 2009. [Bogdanova, O.Yu. (2009). Zaglavie kak semantiko-kompozitsionnyi element khudozhestvennogo teksta (na materiale angliiskogo yazyka) (Title as Semantic and Structural Element of Literary Text). Moscow, 2009 (In Russ.)]

Борисова А.С., Кургузенкова Ж.В., Никишин В.Д. Проблема перевода религиозно-экстремистских текстов в процессе судебной лингвистической экспертизы // Вестник Российского университета дружбы народов. Серия: Лингвистика. 2018. Т. 22. № 2. С. $448-473$. [Borissova, Anna S., Zhanna V. Kurguzenkova, and Vladimir D. Nikishin (2018). Translation of Religious and Extremist Texts: Forensic-Linguistic Expert Examination. Russian Journal of Linguistics, 22 (2), 448 - 473. (In Russ.)] doi: 10.22363/2312-9182-2018-22-2-448-473. 
Бочарникова Н.В. Жанровая идентификация переводного текста как инструмент лингвистического маркетинга // Мир науки, культуры, образования. 2013. Т. 1 (38). 191-194. [Bocharnikova, Natalya (2013). The Genre Identification of The Translated Text as Means of Linguistic Marketing. Mir nayki, kultury i obrazovaniya, 1 (38), 191-194. (In Russ.)]

Бузаджи, Д.М. Хоть горшком назови Текст // Мосты. Журнал переводчиков. 2005.1 (5), С. 64 75. [Buzadzhi, D.M. (2005). Khot' gorshkom nazovi Tekst. Mosty. Zhurnal perevodchikov, 1 (5), 64-75. (In Russ.)]

Васильева Т.В. Когнитивные механизмы формирования и функционирования заголовка // Вестник МГУ. Сер. 19. Лингвистика и межкультурная коммуникация. 2006. № 1. C. 154-171. [Vasil'eva, T.V. (2006). Kognitivnye mekhanizmy formirovaniya i funktsionirovaniya zagolovka (Cognitive Mechanisms of Headlines Forming and Functionning). Vestnik MGU. Ser. 19. Lingvistika i mezhkul'turnaya kommunikatsiya, 1, 154-171. (In Russ.)]

Гарбовский Н.К. Теория перевода: учебник. М.: Изд-во Моск. ун-та, 2004. [Garbovskiy, N.K. (2004). Teorija perevoda (Theory of Translation). Moscow: Moscow University Publ. (In Russ.)]

Гарбовский Н.К. Отражение как свойство перевода. Вестник МГУ. Серия 22. Теория перевода. 2008. № 4. C. 26-36. [Garbovskiy, N.K. (2008). Otrazhenie kak svoictvo perevoda (Reflection as a Property of Translation). Vestnik MGU. Ser. 22. Teoriya perevoda, 4, 26-36. (In Russ.)]

Горшкова В.Е. Перевод в кино: монография. Иркутск: ФГБОУ ВПО «ИГЛУ», 2006 [Gorshkova, V.E. (2006). Perevod v kino: monografiya (Film Translation: monograph). Irkutsk. (In Russ.)]

Горшкова В.Е. Название фильма как единица перевода и составляющая образа-смысла // Вестник ПНИПУ. Проблемы языкознания и педагогики. 2014. № 10. С. 26-36. [Gorshkova, V.E. (2014). Film Title as a Unit of Translation and a Unit of Image-Sense. Vestnik PNIPU. Problemy yazykoznaniya i pedagogiki. 10, 26-36. (In Russ.)]

Горшкова В.Е. Художественный кинодиалог vs документальный: жанровая специфика перевода // Вестник Российского университета дружбы народов. Серия: Лингвистика. 2016. T. 20. No 3. C. 243-259. [Gorshkova, V. E. (2016). Fiction Film Dialogue Vs Documentary Film Dialogue: Genre Peculiarities of Translation. Russian Journal of Linguistics, 20 (3), 243-259 (In Russ.)]

Горшкова В.Е. Седьмая международная научная конференция «Русский язык и культура в зеркале перевода. Мировое кино: вчера, сегодня, завтра...», Афины, Греция, 28 апреля 3 мая 2017 г. // Вестник Российского университета дружбы народов. Серия: Лингвистика. 2017. T. 21. No 4. C. 941-946. [Gorshkova, V.E. (2017). The 7th International Conference "Russian Language and Culture via the cross-cultural translation. World cinema: yesterday, today, tomorrow...” Athens, Greece, 28 April - 3 May 2017. Russian Journal of Linguistics, 21 (4), 941—946. (In Russ.)] doi: 10.22363/2312-9182-2017-21-4-941-946.

Зинкевич О.В. Локализация как процесс лингвистической трансформации структуры и содержания динамического текста // Известия СПбГЭУ. 2018. № 3 (111). C. 135-137. [Zinkevich, O.V. (2018). Lokalizatsiya kak protsess lingvisticheskoi transformatsii struktury i soderzhaniya dinamicheskogo teksta // Izvestiya SPbGEU, 3 (111), 135-137. (In Russ.)]

Клер Р. Кино вчера, кино сегодня. М.: Прогресс, 1981. [Kler, R (1981). Kino vchera, kino segodnya (Cinema: Today and Tomorrow). Moscow: Progress. (In Russ.)]

Климзо Б.Н. Ремесло технического переводчика. Об английском языке, переводе и переводчиках научно-технической литературы. М.: «Р. Валент», 2006. [Klimzo, B.N. (2006). Remeslo tekhnicheskogo perevodchika. Ob angliiskom yazyke, perevode i perevodchikakh nauchnotekhnicheskoi literatury (On English language, Translation and Technical Translators and Interpreters). Moscow: R.Valent (In Russ.)] 
Кныш Е.В. Наименование кинофильмов как объект ономастики // Aктуальные вопросы русской ономастики: Сб. науч. тр. / Отв. ред. Ю.А. Карпенко. Киев, 1988. С. 106-111. [Knysh E.V. (1988). Naimenovanie kinofil'mov kak ob"ekt onomastiki. Aktual'nye voprosy russkoi onomastiki. Kiev, 106-111. (In Russ.)]

Колосов С.А., Матвеев И.А. Вербальный и параграфемный элементы кинопостера в аспекте локализации // Слово и текст: психолингвистический подход. 2015. № 15 С. 77-82. [Kolosov, S.A., Matveev, I.A. (2015). Verbal'nyi i paragrafemnyi elementy kinopostera v aspekte lokalizatsii (Translating Movie Posters: Verbal and Paragraphemic Components). Slovo i Tekst: Psikholingvisticheskii Podkhod, 15, 77-82. (In Russ.)].

Крылова О.А. Лингвистическая стилистика. М.: Высшая школа, 2006. [Krylova, O.А. (2006) Lingvisticheskaya stilistika (Linguistic Stylystics). Moscow: Vysshaya shkola, 2006.

Лассан Э.Р. «Прощание - скорбное слово» (прощание - жанр, концепт, речевой акт?) // Вестник Российского университета дружбы народов. Серия: Лингвистика. 2015. № 3. 7-22. [Lassan, E.R. (2015). Farewell - a Sorrowful Word (Farewell - a Genre, a Concept, a Speech Act?) Russian Journal of Linguistics, 3, 7-22. (In Russ.)]

Милевич И.Г. Стратегии перевода названий фильмов // Русский язык за рубежом. 2007. № 5. C. 65-71. [Milevich, I.G. (2007). Strategii perevoda nazvanii fil'mov (Movie Titles Translation Strategies) Russkii yazyk za rubezhom. № 5, 65-71. (In Russ.)]

Назмутдинова С.С. Гармония как аксиологическая доминанта синергетической модели перевода // Введение в синергетику перевода: монография / под общ. ред. Л.В. Кушниной. Пермь: Изд-во Перм. Нац. исслед. политех. ун-та, 2014. C. 44-67. [Nazmutdinova, S.S. (2014). Garmonia kak aksiologicheskaia dominanta sinergeticheskoj modeli perevoda (Harmony as an Axiological Dominant of Sinergetic Translation Model). In Kushnina L.V. (ed.) Vvedenie v sinergetiku perevoda (Introduction into Translation Synergetics). Perm: National Research Polytechnic University of Perm. (In Russ).]

Оболенская Ю.Л. Художественный перевод и межкультурная коммуникация. Московский гос. ун-т им. М.В. Ломоносова, Филологический факультет. Изд. 3-е, испр. Москва: URSS, 2010. [Obolenskaya, Yu.L. (2010). Khudozhestvennyi perevod i mezhkul'turnaya kommunikatsiya (Literary Translation and Intercultural Communication). 3rd ed. Moscow: URSS. (In Russ.)]

Подымова Ю.Н. Психолингвистические особенности фильмонимов // II Филологический вестник. Научный и образовательный журнал. Майкоп, АГУ. 2005, 7, 172-178. [Podymova, Yu.N. (2005). Psikholingvisticheskie osobennosti fil'monimov (Psycholinguistic Features of Movie Titles). II Filologicheskii vestnik. Nauchnyi i obrazovatel'nyi zhurnal. Maikop, AGU, 7, 172-178. (In Russ.)]

Сдобников В.В., Петрова О.В. Теория перевода: учебник для студентов лингвистических вузов и факультетов иностранных языков. М.: АСТ: Восток-Запад, 2006. [Sdobnikov, Vadim, Petrova, Olga (2006). Teorija perevoda (Translation Theory). Moscow, AST; Vostok-Zapad (In Russ.)]

Слышкин Г.Г., Ефремова М.А. Кинотекст: опыт лингвокультурологического анализа: монография. М.: Водолей Publishers, 2004. [Slyshkin, G.G., Efremova, M.A. (2004). Kino-tekst: opyt kulturologitcheskogo analisa (Film Text: Experience of a Culturological Analysis). Moscow: Vodolei Publishers. (In Russ).]

Снеткова М.С. Лингвостилистические аспекты перевода испанских кинотекстов (на материале русских переводов художественных фильмов Л. Бунюэля «Виридиана» и П. Альмодовара «Женщины на грани нервного срыва»): автореф. дис. ... канд. филол. наук. М., 2009. 
[Cnetkova, M. S. Lingvostilisticheskie aspekty perevoda ispanskikh kinotekstov (na materiale russkikh perevodov khudozhestvennykh fil'mov L. Bunyuelya «Viridiana» i P. Al'modovara «Zhenshchiny na grani nervnogo sryva»): PhD thesis. Moscow, 2009. (In Russ.)]

Тураева 3.Я. Лингвистика текста: учеб. пособие. М.: Просвещение, 1986. [Turaeva, Z.Ya. (1986). Lingvistika teksta (Linguisitics of Text). Moscow: Prosveshchenie. (In Russ.)]

Федорова И.К. Перевод кинотекста в свете концепции культурного переноса: проблема переводческой адаптации // Вестник ЧелГУ. 2009. № 43. С. 142-149 [Fedorova, I.K. (2009). Perevod kinoteksta v svete kontseptsii kul 'turnogo perenosa: problema perevodcheskoi adaptatsii (Text Movie Translation due to the Cultural Transfer Conception: problem of adaptation). Vestnik ChelGU, 43, 142-149 (In Russ.)]

Эко У. Роль читателя. Исследования по семиотике текста / пер. с англ. и итал. С.Д. Серебряного. СПб.: Symposium, 2005. [Eko, U. (2005). Rol' chitatelya. Issledovaniya po semiotike teksta / per. s angl. i ital. (The Role of the Reader. Research on Text Semiotics). S.D. Serebryanogo. SPb.: Symposium. (In Russ.)]

\section{Article history:}

Received: 15 November 2018

Revised: 28 February 2019

Accepted: 18 March 2019

\section{История статьи:}

Дата поступления в редакцию: 15 ноября 2018

Дата принятия к печати: 18 марта 2019

\section{Bionotes:}

VLADISLAV E. ANISSIMOV is Master student at RUDN University. His research interests embrace language, culture and communication; intercultural pragmatics; intercultural communication; discourse analysis; translation studies.

Contact information: e-mail: anisimov.vladislav.95@mail.ru@mail.ru

ANNA S. BORISSOVA is Ph.D., Associate Professor at RUDN University. Her research interests embrace language, culture and communication; intercultural pragmatics; intercultural communication; discourse analysis; translation studies.

Contact information: e-mail: borissovaa_anna@mail.ru

GRIGORIY R. KONSON is Doctor of Art History, Professor, Head of Department of Humanities and Social Science, the Institute of Contemporary Art, Chief Researcher, GITR Film \& Television School, Professor, the Russian State Social University (RSSU). His research interests embrace language, culture and communication; intercultural pragmatics; intercultural communication; discourse analysis; translation studies; national scientific and educational traditions; psychology of personality and social psychology; art history, theory and methodology of Art; philosophical anthropology; academic peer review and publication ethics; organization of international scientific events.

Contact information: e-mail: gkonson@yandex.ru

\section{Сведения об авторах:}

ВЛАДИСЛАВ ЕВГЕНЬЕВИЧ АНИСИМОВ - магистрант 2 года обучения кафедры иностранных языков филологического факультета РУДН. Сфера научных интересов: межкультурная прагматика; межкультурная коммуникация; дискурс-анализ, теория и практика перевода.

Контактная информация: e-mail: anisimov.vladislav.95@mail.ru@mail.ru 
АННА СТЕПАНОВНА БОРИСОВА - кандидат филологических наук, доцент кафедры иностранных языков филологического факультета РУДН. Сфера научных интересов: язык, культура, коммуникация; межкультурная прагматика; межкультурная коммуникация; дискурсанализ, теория и практика перевода.

Контактная информация: e-mail: borissovaa_anna@mail.ru

ГРИГОРИЙ РАФАЭЛЬЕВИЧ КОНСОН — доктор искусствоведения, профессор, заведующий кафедрой общегуманитарных и социальных дисциплин Института современного искусства, главный научный сотрудник Института кино и телевидения, профессор Российского государственного социального университета. Сфера научных интересов: общее языкознание, межкультурная коммуникация, лингвопрагматика, язык и культура, дискурс-анализ, теория и практика перевода, национальные научные и образовательные модели, психология личности и социальная психология, история, теория и методология искусства, философская антропология, академическое рецензирование и этика публикаций, научный менеджмент.

Контактная информация: e-mail: gkonson@yandex.ru 